\title{
Orthopantomography における下顎骨の垂直的高さと
} 歯槽骨吸收度, 歯冠長, 歯根長, おょび解剖学的歯冠

\section{歯根比との関係についての研究}

\author{
吉野雅巳秋山文也角田達彦黒沢 \\ 堀口令一新井高中村治郎 \\ 鶴見大学歯学部第 2 歯科保存学教室 \\ (主任 : 中村治郎教授) \\ (昭和 60 年 12 月 20 日受付)
}

\begin{abstract}
An Orthopantomographic Study of the Relationship between Mandibular Height and Alveolar Bone Resorption, Crown and Root Lengths and Anatomical Crown-root Ratio
\end{abstract}

\begin{abstract}
Masami YOSHINO, Fumiya AKIYAMA, Tatsuhiko TSUNODA, Akira KUROSAWA, Reiichi HORIGUCHI, Takashi ARAI and Jiro NAKAMURA

Department of Periodontics and Endodontics, Tsurumi University School of Dental Medicine
\end{abstract}

(Chief : Prof. Jiro NAKAMURA)

This study was performed to examine if undesirable relationships between mandibular height, tooth crown lenght, root length and crown to root ratio may influence on the etiology of periodontal bone resorption.

One hundred films of orthopantomographs were taken from patients with gingivitis and with light or moderate periodontal disease were used. Those patients were aged from 16 to 78,44 males and 56 females. On film, anatomical crown and root length were measured for lower incisors, canines and premolars. Then, crown-root ratio and bone destruction were calculated. The anatomical crown-root ratio was determined by measuring the level of cementenamel junction. The bone loss from the cement-enamel junction was measured in percentage. The mandi- bular height was measured from cement-enamel junction of each tooth to mandibular plane also. The measuring was carried out by three trained examiners.

The results were as follows in this study.

1. The tooth length had a tendency to be decreased with increasing age.

2. The periodontal bone had a tendency to be destroyed with increasing age.

3. The mandibular height showed an increase with aging.

4. There was not a statistically significant correlation between crown-root ratio between age groups.

5. There was not a statistically significant correlation between mandibular height and bone resorption.

Key words : Orthopantomographs, Mandibular height, Alveolar bone resorption, Crown and root length, 
Anatomical crown-root ratio

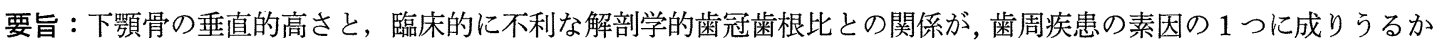
を明らかにするために，下顎骨の垂直的高さと，歯槽骨吸収度，歯冠長，歯根長および解剖学的歯冠歯根比との関係を 比較検討した。

方法は，無作為抽出法により，歯肉炎および軽度ないし中等度の辺縁性歯周炎患者 100 名（男性 44 名，女性 56 名） のオルソパントモ写真を選択し，下顎右側第 2 小臼歯から左側第 2 小臼歯を測定した。

結果 (1) 下顎骨の垂直的高さ (CEJ-下顎骨下縁間距離) は加齢に伴ない増加した。(2) 歯の長さは加齢に伴ない減少 した。(3) 歯槽骨吸収度は加齡に伴ない増加した。(4) 解剖学的歯冠歯根比は年齢群間に統計的有意差は認められなかっ た。(5) 下顎骨の垂直的高さと歯槽骨吸収度との間には相関性は認められなかった。

索引用語 : オルソパントモ写真, 下顎骨の垂直的高さ, 歯槽骨吸収度, 歯冠および歯根長, 解剖学的歯冠歯根比

\section{緒言}

歯と顎骨の不調和は，不正咬合の原因として矯正学の 分野での研究が多く, 現在では歯と顎骨の不調和自体が 不正咬合の主要な病因として考えられている( 8)。井上 は, 歯と顎骨の不調和とう蝕や歯周病との関係に着目 し, 数年来古人骨を調査し, 近年現代人の歯と顎骨の不 調和の生ずる要因の 1 つとして, 食生活の発達に伴なう 食物性状の変化により, 咀嚼機能量の低下が生じ, 咀嚼 筋群と顎骨の縮小の誘因となり， 2 次的に歯の退化とな ると報告した ${ }^{8)}$ 。また顎骨执よび歯周組織の老化に関す る病理組織学的研 究では, Thomas $(1946)^{9)}$, Boyle $(1955)^{10)}, \operatorname{Glickman}(1958)^{11)}$, 浦郷 $(1978)^{12)}$, 李 (1979) $ら^{13)}$ は, 歯槽縁の退縮は生理的な老人性萎縮により起こ ると述べている。

一方 Glattes $(1936)^{14)}$, 秋吉 $(1972)^{15)}$, 江澤 (1984) ら 16 17) は歯槽縁の吸収は炎症状態によって変化すると 唱えるなど議論の的となってきた。Brow $\mathrm{n}^{18)}$, 本教室の 上原 ${ }^{19)}$, および堀口ら ${ }^{20)}$ などによって, 歯槽骨破壊と解 剖学的歯冠歯根比との関連について報告されてきた。し かし今までに, 下顎骨と解剖学的歯冠歯根比, および歯 槽骨吸収度についての報告は, Björn (1969) ら ${ }^{21)}$ の報告 があるが，日本では比較的少ない。

そこで今回我々は，歯を支持する下顎骨の垂直的高さ と, それに伴なう臨床的に不利な歯冠長, 歯根長, およ び解剖学的歯冠歯根比が, 歯周疾患の種々な素因の 1 つ と成りうるかを明らかにするためにオルソパントモグラ フィーを用いて，下顎骨の垂直的高さ（CEJ から下顎 骨下縁までの距離）と歯冠長, 歯根長, 歯槽骨の吸収度 および解剖学的歯冠歯根比との関連について比較検討し た。

\section{材料と方法}

\section{1. 測定資料}

昭和 57 年から 58 年度, オルソパントモグラフィー (装置 ; 東京エミックス社製 PALMIN $^{\mathrm{FA}}$, 管電圧 65〜95 $\mathrm{KVp}$, 管電流 $12 \mathrm{~mA}$ 一定）を所有している都内 2 力所 の歯科医院に受診した患者の内, 歯肉炎, および軽度な いし中等度の歯周疾患と診断された患者より得られたオ ルソパントモグラフィー写真から無作為抽出法を用い, 患者 100 名 (男性 44 名, 女性 56 名, 年齢 16〜 78 歳, 平 均年齢 48, 7 歳) を選択し測定資料とした (Fig. 1)。

被測定者の年齢と性別分布を Table 1 に示す。30歳 以下, $30 \sim 49$ 歳, 50 歳以上の 3 つの年齢層に分けると, 30 歳以下および 30〜 49 歳の者はほぼ同数で, 全体の 40 \%ずっとなった。また男女別の割合は，30 歳以下，30〜 49 歳では, 女性が男性より多く, 50 歳以上では逆に男性 が多かった。

\section{2. 測定方法}

Björn らの上顎洞底および根尖から歯槽骨骨頂部まで の距離を測定した方法 ${ }^{21)}$ (Fig．2）を参考にして，X線 写真上で被測定歯の下顎骨の垂直的高さ，歯冠長，歯根 長, 歯槽骨の吸収度および解剖学的歯冠歯根比を以下の ようにして測定した。

測定部位は下顎右側第 2 小囦歯から左側第 2 小臼歯で あり, クラウンや大きな修復物の装着されている場合, 像の抗大, ボケ, 障害陰影などは不適当な資料として除 外した。

Fig. 3 に示すように, 被測定歯の歯軸と平行に近遠心 に分けて, 切縁からセメント・エナメル境までの距離を $\mathrm{c}_{1}, \mathrm{c}_{2}$, セメント・エナメル境から根尖までの距離を $\mathrm{r}_{1}, \mathrm{r}_{2}$, セメント・エナメル境から歯槽骨骨頂部の歯面側までの 距離を $\mathrm{d}_{1}, \mathrm{~d}_{2}$, 歯槽骨骨頂部の歯面側から下顎骨下縁ま 


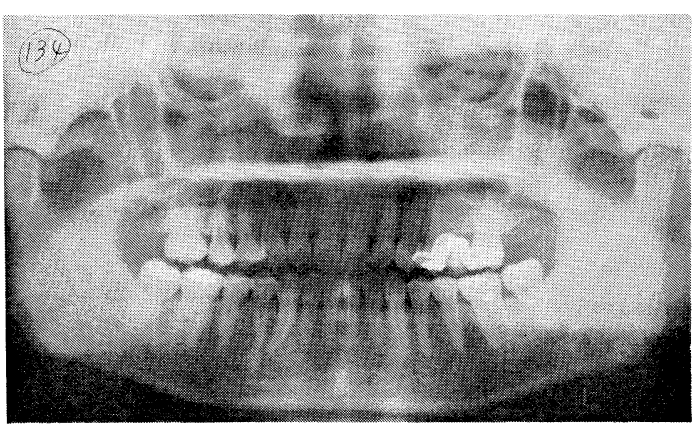

Fig. 1 An orthopantomography taken from a patient with slight degree of periodontal disease

Table 1 AGE and SEX

\begin{tabular}{r|c|c|c}
\hline \multicolumn{1}{l|}{ AGE } & MALE & FEMALE & TOTAL \\
\hline-29 & 17 & 24 & 41 \\
\hline $30-49$ & 15 & 23 & 38 \\
\hline $50-$ & 12 & 9 & 21 \\
\hline TOTAL & 44 & 56 & 100 \\
\hline
\end{tabular}

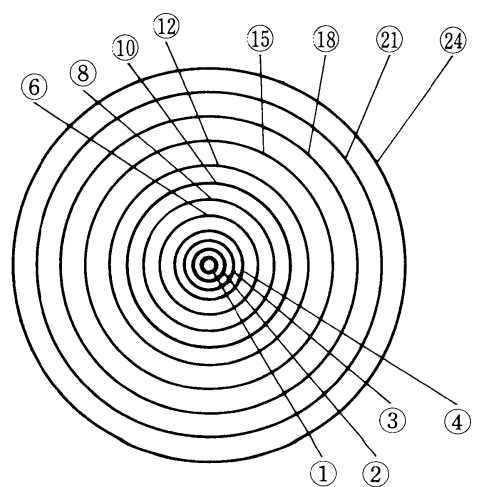

Fig. 2 Transparant ruler used for measurements of the relation of the floor of the sinus to the apices and to the alveolar bone margin (After Björn 1969)

での距離を $\mathrm{a}_{1}, \mathrm{a}_{2}$, とする計 8 カ所を計測位置とした。測 定に用いたスケールは $0.5 \mathrm{~mm}$ 精度 JIS 1 級金属直尺を 用いた。計測は 1 力所あたり 3 回ずつ行ない, 平均值を 測定值とした。尚, 実際の測定は 3 人の測定者によって 行なわれ，予備実験で 3 者間の測定能力に有意差は認め られなかった。

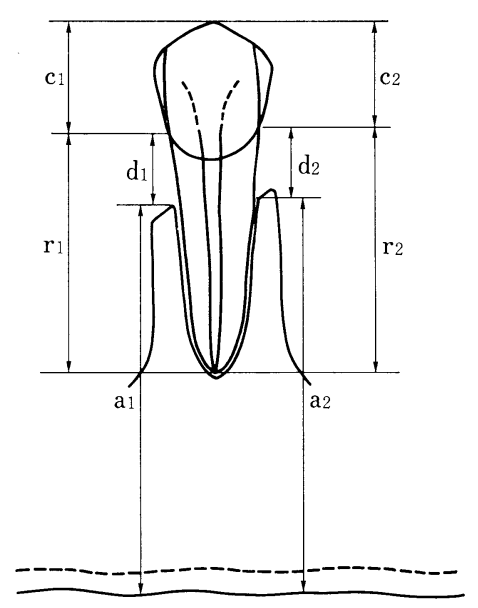

Fig. 3 Measuring points

\section{3. 測定項目}

測定值に基づき以下のごとく計算を行なった。

(1) 下顎骨の垂直的高さ

(CEJ-下顎骨下縁間距離)

$$
\mathrm{M}=\frac{1}{2}\left(\mathrm{a}_{1}+\mathrm{a}_{2}+\mathrm{d}_{1}+\mathrm{d}_{2}\right)
$$

(2) 歯冠長

$$
\mathrm{C}=\frac{1}{2}\left(\mathrm{c}_{1}+\mathrm{c}_{2}\right)
$$

(3) 歯根長

$$
\mathrm{R}=\frac{1}{2}\left(\mathrm{r}_{1}+\mathrm{r}_{2}\right)
$$

(4) 歯の長さ

$$
\mathrm{T}=\mathrm{C}+\mathrm{R}
$$

(5) 歯槽骨の吸収度

$$
\mathrm{D}=\frac{1}{2}\left(\frac{\mathrm{d}_{1}}{\mathrm{r}_{1}}+\frac{\mathrm{d}_{2}}{\mathrm{r}_{2}}\right) \times 100(\%)
$$

(6) 解剖学的歯冠歯根比

$$
\mathrm{K}=\frac{1}{2}\left(\frac{\mathrm{c}_{1}}{\mathrm{r}_{1}}+\frac{\mathrm{c}_{2}}{\mathrm{r}_{2}}\right)
$$

以上の項目を, 年齢群 (30 歳以下, $30 \sim 49$ 歳, 50 歳以 上）に分け，平均値の差の検定を行なった。

\section{成 績}

\section{1. 下顎骨の垂直的高さ, 歯根長および歯の長さ} (Table 2, Fig. 4)

30 歳未満の下顎骨の垂直的高さを示す群 では, 42.05 $\pm 3.71 \mathrm{~mm}$ であるのに対し，30〜 49 歳の群および 50 歳 以上の群では，それぞれ $43.41 \pm 4.85 \mathrm{~mm}, 45.42 \pm 3.55$ $\mathrm{mm}$ と増加し, 30 歳未満の群と 50 歳以上の群との間に 
Table 2 Mandibular height (CEJ-Mandibular plane), root length, tooth length and age

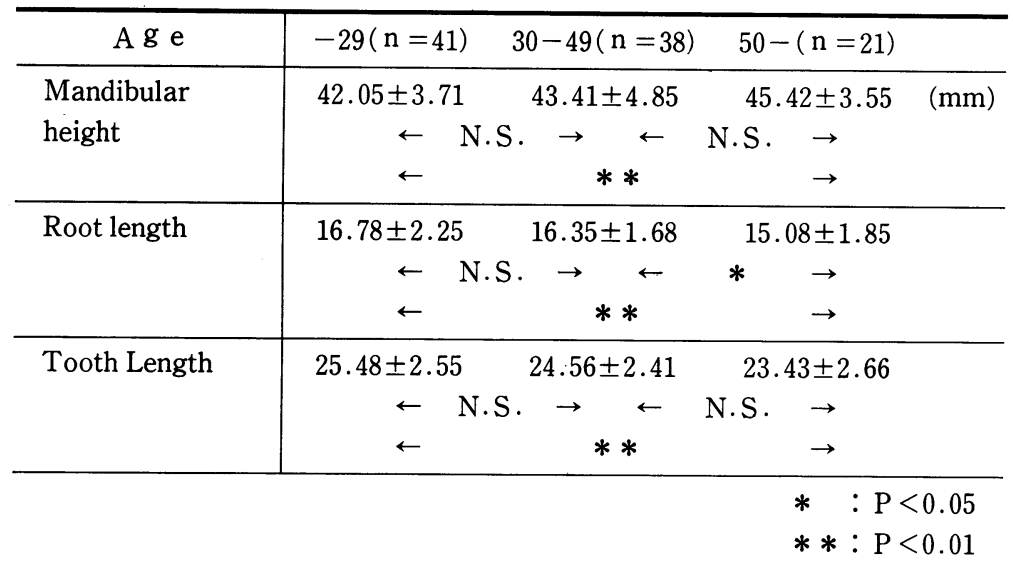

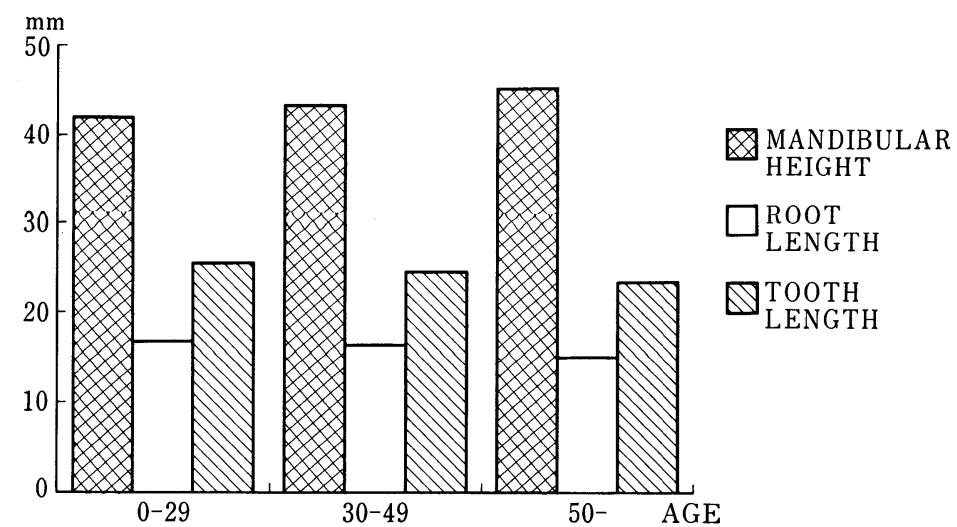

Fig. 4 Mandibular height, root length, tooth length

Table 3 Alveolar bone resorption and age

\begin{tabular}{l|cccc}
\hline \multicolumn{1}{c|}{ A g e } & $-29(\mathrm{n}=29)$ & $30-49(\mathrm{n}=49)$ & $50-(\mathrm{n}=21)$ \\
\hline Alveolar bone & $13.29 \pm 6.04$ & $19.40 \pm 9.74$ & $25.46 \pm 13.00$ & $(\%)$ \\
resorption & $\leftarrow$ & $* *$ & $\rightarrow$ & $\rightarrow$ \\
\hline \multicolumn{5}{c}{} \\
& $\leftarrow$ & $* *$ & $* \mathrm{P}<0.05$ \\
\end{tabular}

のみ, 危険率 $5 \%$ で推計学的に有意差が認められた。こ れに対して, 歯根長および歯の長さは, 年齢の増加に伴 ない減少した。すなわち 30 歳未満の歯根長を示す群で は, $16.78 \pm 2.25 \mathrm{~mm}$ であるのに対し, 30〜49 歳及び 50 歳以上の群では, それぞれ $16.35 \pm 1.68 \mathrm{~mm}, 15.08 \pm$ $1.85 \mathrm{~mm}$ となり，また 30 歳未満の歯の長さを示す群で は, $25.48 \pm 2.55 \mathrm{~mm}$ であるのに対し, 30〜49 歳, 50 歳 以上ではそれぞれ $25.56 \pm 2.41 \mathrm{~mm}, 23.43 \pm 2.66 \mathrm{~mm}$
となり, 歯根長, 歯の長さともに 30 歳以下の群と, 50 歳以上の群との間にのみ, $\mathrm{t}$ 検定の結果, 危険率 $5 \%$ で 推計学的に有意差が認められた。

2. 年齢群別の歯槽骨吸収度 (Table 3, Fig. 5)

30 歳末満の群では, $13.29 \pm 6.04 \%$ に対し, 30４9歳 では, $19.40 \pm 9.74 \%, 50$ 歳以上では, $25.46 \pm 13.0 \%$ と なり, 30 歳未満の群と他の 2 群との間に危険率 $1 \%$ で推 計学的に有意差を認めたが, 30〜 49 歳と 50 歳以上の群 
との間には差は認められたものの，有意差は認められな かった。

3. 年齢群別の解剖学的歯冠菌根比 (Table 4, Fig. 6) 30 歳未満の群, $30 \sim 49$ 歳の群および, 50 歳以上の群で はそれぞれ $0.50 \pm 0.01,0.52 \pm 0.01,0.51 \pm 0.01$ となり， それぞれの閒に推計学的に有意差は認められなかった。

4. 下顎骨の垂直的高さ之歯槽骨吸収度 (Fig. 7, 8, 9)

30 歳末満の群, $30 \sim 49$ 歳の群および 50 歳以上の群の いずれの年齢群において下顎骨の垂直的高さと歯槽骨吸 収度との相関性は認められなかった。

\section{考察}

上原ら ${ }^{19)}$ は，一般的な患者を対象に抜去歯を用いて計 測し, 歯周疾患の原因で抜去された歯と, 対照として計 測した解剖体の歯との両者の解剖学的歯冠歯根比を比較 した結果，前者の方が大きい傾向が見られたと述べてい る。また堀口ら ${ }^{20)}$ は, 中等度の歯周疾患患者の歯冠歯根 比と歯槽骨破壊との関係を, 口内法X線写真を用いて比 較検討し，上顎においては，両者の間に有意差は認めら れなかったが, 下顎においては, 歯冠歯根比の歯槽骨吸 収に対する影響がある程度考えられると報告している。 さらには Brown ら ${ }^{18)}$ の報告に示すように，モンゴリズ ムによる知能障害者が歯周疾患となった場合, 特徴的短 根歯の為に, 解剖学的歯冠歯根比が好ましくないことか

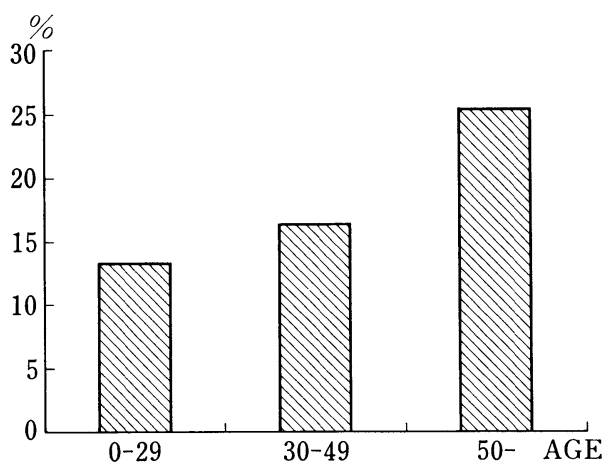

Fig. 5 Alveolar bone resorption

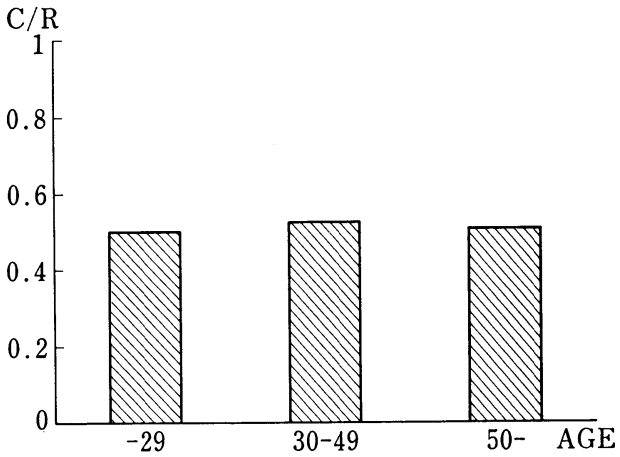

Fig. 6 Anatomical crown to root ratio

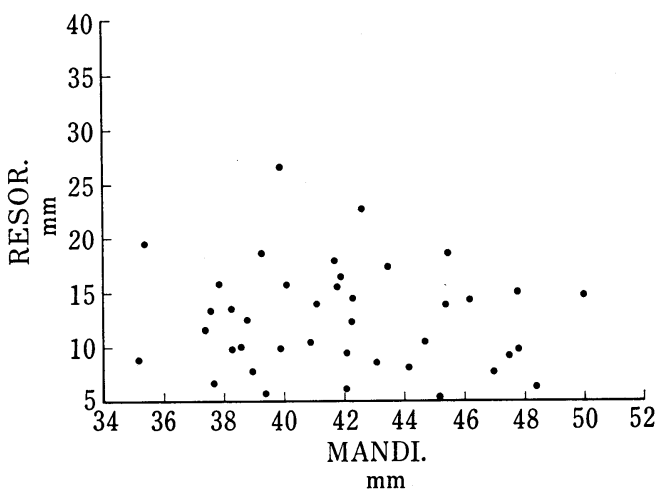

Fig. 7 Correlation of between mandibular height and bone resorption $<30$ AGE groups

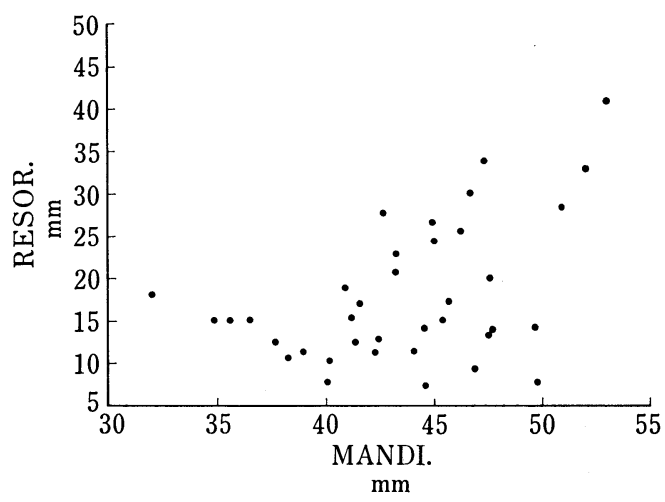

Fig. 8 Corrlation of between mandibular height and bone resorption 30-49 AGE groups

Table 4 Anatomical crown to root ratio and age

\begin{tabular}{|c|c|c|c|}
\hline A g e & $-29(\mathrm{n}=41)$ & $30-49(\mathrm{n}=39)$ & $50-(\mathrm{n}=21)$ \\
\hline $\begin{array}{l}\text { Anatomical } \\
\text { crown to root } \\
\text { ratio }\end{array}$ & $\begin{aligned} & 0.50 \pm 0.01 \\
& \leftarrow \quad \text { N.S. } \\
& \leftarrow\end{aligned}$ & $\stackrel{0.52 \pm 0.01}{\leftarrow} \underset{\text { N.S. }}{\leftarrow}$ N.S. & $\begin{array}{l}0.51 \pm 0.01 \\
\quad \rightarrow \\
\rightarrow\end{array}$ \\
\hline
\end{tabular}




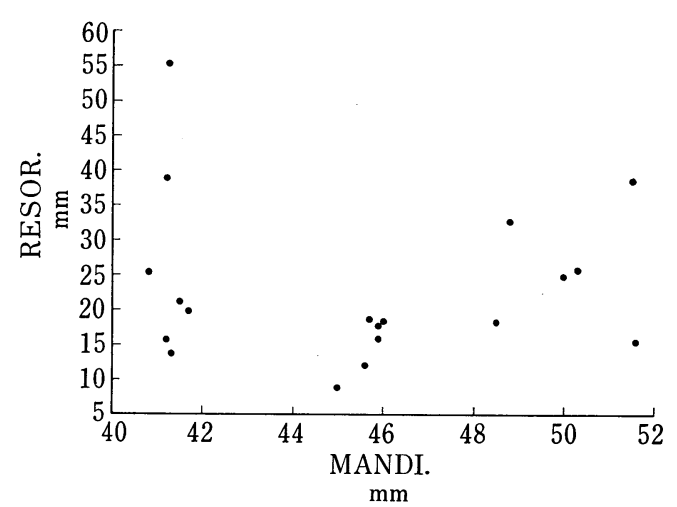

Fig. 9 Correlation of between mandibular height and bone resorption $50 \leqq \mathrm{AGE}$ groups

ら，早期動摇と，早期脱落を招くことを示唆した。

本研究では, 上記の報告を一歩進めて，歯を支持する 下顎骨に着目し, 日常使用頻度が比較的多いオルソパン トモグラフィーを用い, 歯周組織の破壊に対して歯冠 長, 歯根長, 解剖学的歯冠歯根比および下顎骨に影響を 与えるか否かを検討した。

1）下頡骨の垂直的高さ (CEJ-下頡骨下縁間距離) と 歯槽骨吸収度

歯槽骨吸収度については, 今回の調查結果では加龄に 伴ない増加傾向が示されたが，歯槽骨の吸収と年齡に関 しては, 浦郷 ${ }^{12)}$, 李 ${ }^{13)}$ ，は歯槽骨の吸収は生理的に生ず る老人性萎縮と報告している。しかし 秋吉 ${ }^{15)}$, 江澤ら 16 17) は歯槽骨の吸収, 歯周組織破壊の程度は, 炎症の強 さと関連が強く, 歯槽骨吸収と年齢とは相関性を示さな いと報告している。

歯周組織の破壊の原因が，プラーク，歯石，不良充填 物, 咬合性外傷などの為に, プラークと Host parasite relation の変化によることは衆知のごとくである。石 川ら 22)の報告でも, 疫学的調查によって歯槽骨の生理的 な老人性吸収と言う考え方には疑問があると述べてい る。歯槽骨の吸収度を観察する為には, オルソパントモ グラフィーは不適当と考学る。

下顎骨の垂直的高さは，本来は歯槽骨骨頂から下顎骨 下縁間距離とすべきだが, 上記のごとく歯槽骨縁の位置 が様々なので, 今回は, CEJ を基準として, CEJ-下顎骨 下縁間距離と年齢との関係を調べた。下顎骨垂直的高さ の増皊変化の要因として 2 つ考えられる。

1 つは Gottlieb ${ }^{23)}$, Orban ら ${ }^{24)}$ の報告に基づき, 挺出 傾向によると思われる。もう 1 つは井上4) の報告に基ゔ き高年齢者に比べて若年齢者の䫈骨の縮小化によると考 えられる。
2）歯の長さと解剖学的歯冠歯根比

歯の長さが加齢に伴ない減少傾向を示した原因とし て, 主に咬耗によると思われる。解剖学的歯冠歯根比の 各年噛群について有意差が認められなかった原因とし て, 資料数や, 計測方法によると思われ, 今後検討を加 える必要があると思われる。

3）下顎骨の垂直的高さと歯槽骨吸収度

下頷骨の垂直的高さと歯槽骨吸収度との間に相関性が 認められなかった原因として, 主に局所的原因が考えら れる。この為口腔内所見を詳細に検討する必要があると 思われる。

今後歯周疾患診查 (PI, OHI, PD, 動摇度など) 罹患状 態や病変の進行別に症例を増加し, 個々の診查所見を総 合的に観察することが, 将来歯周疾患の予防対策をたて る上にも考慮すべき点と思われる。これらの点について はさらに詳細な調査検討が必要であろう。

\section{総括および結論}

下顎骨の垂直的高さと歯周疾患の素因の 1 つに成りう るかを明らかにするために, 下頡骨の垂直的高さと, 歯 槽骨吸収度, 歯冠長, 歯根長, および解剖学的歯冠歯根 比との関係を比較検討した。

資料として, 下顎右側第 2 小臼歯から左側第 2 小臼歯 が健全な, 歯肉炎, および軽度ないし中等度の辺縁性歯 周炎と診断された患者 (男性 44 名, 女性 56 名, 年歯 16〜78 歳, 計 100 名, 平均年齢 48.7 歳) のオルソパン トモグラフィーを無作為抽出法により選択し, 上記各項 目を計測した。

その結果以下の結論を得た。

1. 下顎骨の垂直的高さ (CEJ-下額骨下縁間距離) は 加齢に伴ない増加傾向を示した。

2. 歯の長さは加齢に伴ない減少傾向を示した。

3. 歯槽骨の吸収度は加齢に伴ない増加傾向を示し た。

4. 解剖学的歯冠歯根比と年齢群間との間に, 統計的 有意差は認められなかった。

5. 下顎骨の垂直的高さと歯槽骨吸収度との間には相 関性は認められなかった。

尚この研究は, 昭和 60 年度文部省科学研究費総合研究 $\mathrm{A}$ “崡 周疾患の疫学的研究” (No, 59370046, 代表中村治郎教授) の援 助のもとに行われた。 


\section{文献}

1）井上直彦, 鈴木祥井 : 最新歯科矯正アトラス, 医 歯薬出版, 東京, 1971,362 .

2）井上直彦: 管理と処理の体系としての歯 科 矯 正 学. 歯界展望, $51: 81-89,1978$.

3）井上直彦：咬合育成と発達歯科医学. 歯界展望 $53:$ 75-83，223-230, 1979.

4）井上直彦：咬合育成と discrepancy. 歯界展望別 冊こどもの歯科 : 252-261, 1979.

5）井上直彦：いわゆる discrepancy について。日本 歯科評論, $448: 141-150,1980$.

6）井上直彦：いわゆる discrepancy について. 日本 歯科評論, 449 : 151-161, 1980.

7）井上直彦：いわゆる discrepancy について. 日本 歯科評論, $450: 133-145,1980$.

8）井上直彦：いわゆる discrepancy について。 日本 歯科評論, $451: 33-46,1980$.

9) Thomas, B.O.A. : "Gerodontology" : The study of changes in oral tissue associated with aging. J. Am. Dent. Assoc., $33: 207-213$, 1946.

10) Boyle, P.E. : Kroufeld's Histopathology of the teeth, Philadelphia., 377, 1955.

11) Glickman, I. : Clinical periodontology, 6th ed., Saunders, Philadelphia, 1958.

12）浦郷篤史, 舟越啓右, 李載 仁, 津两実, 徳富 敏信，佐藤良一，末森多賀生：頷骨の老化に関寸 る病理組織学的研究．歯界展望（臨時増刊） 51 ： 1040-1041， 1978.

13）李 載仁：下顎の老化に関する病理組織学的研 究. 九州歯会誌, $32: 564-589,1979$.

14) Glattes, M. : Mikroskopishe Untersuchungen am normalbelasteten Alveolarknochen in verschiederen Altersstufen. Dtsch. Zahnusw, HK, $3: 827,1936$.

15）秋吉正豊 : 歯周組織の構造と病理, 第 2 版, 医歯 薬出版, 1972， 248.

16）江澤敏光：現代日本人乾燥頭蓋における歯槽骨の 厚さ及び形態. 日歯周誌， $26: 243-256,1984$.

17）江澤敏光, 佐野裕士, 奥野健二, 古川 清, 伊藤 公一，村井正大：現代日本人乾燥頭蓋における Bone level と年齢の関連について.日歯周誌, $27: 610-617,1985$.

18) Brown, R.H. : Crown and root length, and root-crown ratios of mongoloido, non-mongoloid retarded and normal individuals. J. Periodont. Res., 6 : 140-145, 1971.

19）上原茂敬，堀口令一，近内レイ子，森山倫子，堀 内町子, 新井 高, 中村治郎：歯周疾患の素因と しての歯冠歯根比. 日歯周誌, $21: 72-77,1979$.

20）堀口令一，柳田美佐子，兽田麻美子，上原茂敬, 新井 高, 中村治郎：X線写真による歯冠歯根比 と歯槽骨破壊との関連についての研究. 日歯周誌, $20: 355-341,1978$.

21) Björn, H. and Holmberg, K. : Maxillary sinus in periodontal disease. A clinical and radiographic investigation. Odont. Rev. $18: 83-114$, 1967.

22）石川 純，松江一郎，鈴木康司，浜田征雄，山崎 敬介, 前田 勝: 成人集団にお打る歯周疾患の調 查. 口病誌, $34: 412-418,1967$.

23) Gottlieb, B. : What is a nomal pocket? J. Am. Dent. Assoc. 13 : 1747-1751, 1926.

24) Orbann, B. : Histology and physiology of the gingiva. J. Am. Dent. Assoc. 44 : 624-628, 1952. 